\title{
PERTARUNGAN SIMBOLIK DALAM SLOGAN PILKADA SULAWESI SELATAN TAHUN 2020: SUATU TINJAUAN ANALISIS WACANA KRITIS PIERRE BOUDIEU
}

\author{
Selfiani, Mayong Maman, dan Usman \\ Program Pascasarjana Magister Pendidikan Bahasa (Bahasa Indonesia), Universitas \\ Negeri Makassar, Makassar, Sulawesi Selatan, Indonesia \\ selfyfy9@gmail.com
}

\begin{abstract}
ABSTRAK: Penelitian ini bertujuan untuk merepresentasikan bentuk-bentuk pertarungan simbolik aspek eufemisasi dan aspek sensorisasi dalam slogan pilkada Sulawesi Selatan tahun 2020. Fokus penelitian ini yaitu slogan pilkada Sulawesi Selatan tahun 2020. Jenis penelitian deskriptif yang digunakan dalam penelitian ini mengacu pada pendekatan kualitatif. Teknik pengumpulan data yang digunakan adalah teknik dokumentasi, teknik baca, dan teknik catat. Data dalam penelitian ini adalah kata, frasa, klausa, dan kalimat yang memuat slogan pilkada Sulawesi Selatan tahun 2020. Sumber data dalam penelitian ini adalah media cetak berupa spanduk, banner, baliho dan stiker kampanye kandidat pilkada Sulawesi Selatan tahun 2020. Teori yang digunakan sebagai acuan untuk menganalisis bentuk pertarungan simbolik adalah teori analisis wacana kritis Pierre Bourdieu.Hasil dalam penelitian ini ditemukan 14 bentuk pertarungan simbolik dalam slogan pilkada Sulawesi Selatan Tahun 2020. Pertarungan simbolik aspek eufemisasi yang ditemukan terdiri atas bentuk perubahan, kebangkitan, keren, harapan, lanjutkan, kebersamaan, persatuan, kesejahteraan, kebaruan, identitas, dan merakyat. Pertarungan simbolik yang menggunakan aspek sensorisasi terdiri atas bentuk sindiran, kejujuran dan kesantunan.
\end{abstract}

KATA KUNCI: Pertarungan Simbolik, Eufemisasi, Sensorisasi, Pilkada

ANALYSIS OF LANGUAGED CRIMES IN SOCIAL MEDIA

(FORENSIC LINGUISTIC)

\begin{abstract}
The study aims to represent the symbolic forms of euphemism and censorship aspects in regional election slogans in South Sulawesi in 2020. The focus of the study is the regional election slogans in South Sulawesi in 2020. The type of descriptive research used in this study refers to a qualitative approach. Data collection techniques used were documentation, reading, and note-taking techniques. The data in this study were words, phrases, clauses, and sentences that contained slogans for the regional elections in South Sulawesi in 2020. The data sources in this study were printed media in the forms of banners, billboards, and campaign stickers for the regional election candidates campaign in South Sulawesi in 2020. The reference for analyzing the form of symbolic battles employed Pierre Bourdieu's theory of critical discourse analysis. The results of the study discovered 14 forms of symbolic battles in regional elections slogans in South Sulawesi in 2020. The symbolic battles of euphemism aspects which were discosvered consisted of the forms of change, revival, coolness, hope, continue, togetherness, unity, prosperity, novelty, identity, and populist. The symbolic battles that used censorship aspect consisted of satire, honesty, and politeness.
\end{abstract}

KEYWORDS: Symbolic Battle, Euphemism, Censorship, Regional Elections.

\begin{tabular}{cccc}
\hline Diterima: & Direvisi: & Distujui: & Dipublikasi: \\
2021-09-01 & 2021-07-08 & 2021-09-01 & 2021-10-29 \\
Pustaka & : Selfiani, S., Maman, M., \& Usman, U. (2021). PERTARUNGAN SIMBOLIK DALAM \\
& SLOGAN PILKADA SULAWESI SELATAN TAHUN 2020: SUATU TINJAUAN \\
& ANALISIS WACANA KRITIS PIERRE BOUDIEU. Fon: Jurnal Pendidikan Bahasa dan \\
& Sastra Indonesia, 17(2), 146-158. doi:https://doi.org/10.25134/fon.v17i2.4430 \\
\hline
\end{tabular}

\section{PENDAHULUAN}

Pemilihan kepala daerah secara langsung pertama kali diselenggarakan pada tahun 2005 dengan berlandaskan UU No. 32 Tahun 2004 tentang Pemerintahan Daerah. Pada pelaksanaanya, pilkada 
secara langsung merupakan hasil dari proses pembelajaran demokrasi di Indonesia yang berlangsung sejak zaman kemerdekaan sampai saat ini.

Penelitian ini penting untuk dilakukan, karena pertama pemilihan kepala daerah menjadi salah satu pintu untuk menciptakan masyarakat yang sejahtera, adil, dan makmur sehingga masyarakat harus mampu memilih calon kepala daerah yang tidak semata-mata menawarkan janji kampanye melalui bahasa yang memikat akan tetapi mempertimbangkan kapasitas atau kemampuan yang dimiliki. Kedua, penggunaan bahasa pada slogan kampanye diusung sedemikian menarik oleh kandidat kepala daerah untuk mendapatkan simpati masyarakat. Melalui bahasa tersebut, aktor-aktor sosial menyampaikan ideologinya secara halus dengan menggunakan mekanisme kekerasan simbolik sebagai salah satu bentuk pertarungan simbolik.

Sulawesi Selatan adalah salah satu provinsi yang menyelengga-rakan pemilihan kepala daerah serentak tahun 2020. Pilkada tersebut diikuti 12 kabupaten kota di antaranya Kota Makassar (pilkada ulang tahun 2018), Pangkajene Kepulauan, Barru, Gowa, Maros, Soppeng, Luwu Timur, Luwu Utara, Bulukumba, Tana Toraja, Kepulauan Selayar, dan Toraja Utara. Kandidat yang mengikuti pemilihan kepala daerah tersebut berasal dari berbagai latar belakang dan profesi. Mulai dari pengusaha, tokoh masyarakat, dokter, polisi, tokoh politik, dosen, dan pegawai negeri sipil.

Politikus sering mengguna-kan pilihan bahasa pada saat kampanye yang berisi ajakan maupun himbauan, misalnya stop korupsi, stop money politic, dan menjanjikan banyak perubahan mulai dari kesejahteraan di bidang pendidikan, kesehatan, ekonomi dan sosial. Namun pada kenyataannya, setelah mereka terpilih tidak sedikit dari janji yang mereka ucapkan hanya pemanis untuk mendapatkan dukungan dari masyarakat. Kurang-nya pemahaman dan pengetahuan masyarakat tentang kompetensi dan latar belakang dari kandidat calon kepala daerah membuat mereka menilai secara terbatas. Oleh karena itu, diharapkan melalui kajian ini ada kontruksi bahasa yang dapat dikembangkan dan ditemukan untuk menjadi model pendidikan karakter dalam pesta demokrasi melalui praktik bahasa.

Slogan kampanye yang diusung masing-masing kandidat me-rupakan pertarungan yang dilakukan secara tidak langsung. Pertarungan yang dimaksud adalah pertarungan simbolik. Mengkaji pertarungan simbolik dalam wacana politik, khususnya pesta demokrasi 2020 tentu memerlukan analisis secara mendalam, termasuk mekanisme yang terdapat di dalamnya. Perta-rungan simbolik identik dengan kekerasan simbolik yang menggu-nakan elemen eufemisasi dan sensorisasi. Selain itu, faktor sosio-kultural menjadi salah satu penentu bagi para kandidat dalam memperjuangkan ideologinya, hal tersebut dapat diamati melalui habitus, modal, dan arena. Teori analisis wacana kritis yang sesuai dengan uraian di tersbut adalah teori yang dikemukakan oleh Pierre Bourdie.

Analisis wacana kritis Pierre Bourdieu mencakup tiga gagasan yaitu habitus, modal, dan arena atau ranah. Memahami kekuasaan dan kekerasan simbolik mengharuskan pemahaman kita akan peran bahasa sebagai sistem simbol. Selain berperan sebagai sistem komunikasi dalam memahami dan menyampaikan pikiran serta perasaan antar-manusia, bahasa memiliki peran laten yang seringkali tidak disadari, yaitu sebagai praktik kekuasaan. Dengan mengunakan simbol-simbol bahasa, ideologi yang terdapat di baliknya dapat 
disematkan perlahan-lahan secara tidak kentara. Dominasi terhadap simbol tersebut merupakan kekua-saan yang membuat orang mengenali, memperkuat dan mengu-bah pandangan mereka mengenai dunia.

Berberapa penelitian telah dilakukan dengan menggunakan analisis wacana kritis Pierre Bourdie mengenai pertarungan simbolik sebagai pisau bedah, seperti Jufri (2014) dengan judul penelitian "Pertarungan Simbolik dalam Wacana Calon Legislatif”. Penelitian ini bertujuan mendeskripsikan bentuk konstruksi pertarungan simbolik dalam wacana pesta demokrasi, mengeksplanasi model habitus dan arena serta representasi linguistik sebagai konstruksi dalam pertarungan simbolik wacana pesta demokrasi dalam pemilu. Hasil dari penelitian tersebut yaitu ditemukan nilainilai yang dikonstruksi partai politik/caleg. Ditemukan banyak bentuk pertarungan dalam upaya partai politik membentuk opini publik.

Penelitian selanjutnya dilaku-kan oleh (Jufri \& Tolla, 2014) dengan judul "Representasi Linguistik dalam Pertarungan Simbolik Wacana Iklan Komersil". Penelitian ini bertujuan untuk mendeskripsikan wujud linguistik yang digunakan pada pertarungan simbolik dalam wacana iklan komersil di media massa. Kemudian, Syaf (2017) melakukan penelitian dengan judul "Pertarungan Simbol Identitas Etnis Sebagai Komunikasi Politik dalam Pilkada Kota Makassar". Temuan dari penelitian tersebut yaitu Ramdhan Pomanto membangun model komunikasi politik berbasis "Koneksitas Modal Simbolik" dengan menyentuh ruang sosio-kultural dan emosional pemilih, melalui politik bahasa “Ana' Lorongna Makassar. Bahasa 'Ana Lorongna Makassar adalah kontruksi 'Negoisasi Identitas' yang dijalankan oleh Ramdhan Pomanto untuk menghadapi stigma pelabelan, dan stereotype sebagai orang di luar kelompok yang berusaha menolaknya dari ranah pertarungan walikota Makassar.

Berdasarkan latar belakang masalah yang telah diuraikan, dengan mencermati karakteristik, konsep, masalah, peneliti mene-mukan peluang untuk melakukan penelitian dengan judul "Pertarungan Simbolik dalam Slogan Pilkada Sulawesi Selatan Tahun 2020 (Analsis Wacana Kritis Pierre Bourdieu). Jadi, objek penelitian ini hanya berfokus pada wacana atau bahasa yang digunakan oleh kandidat dalam slogan kampanye pilkada Sulawesi Selatan tahun 2020. Teori utama yang digunakan dalam penelitian ini adalah teori analisis wacana kritis yang dikembangkan oleh Pierre Bourdieu. Selanjutnya, data yang diperoleh dianalisis menggunakan jenis penelitian kualitatif.

\section{LANDASAN TEORI}

\section{A. Teks}

Secara etimologis istilah "wacana" berasal dari bahasa Sanse-kerta wach/wak/vak yang artinya berkata, berucap. Dalam dunia linguistik kata wacana digunakan sebagai bentuk terjemahan dari istilah bahasa Inggris "Discourse". Bila ditelusuri kata discourse berasal dari bahasa latin discursus yang berarti lari kesana, kemari, lari bolak-balik. Kata itu diturunkan dari dis (dari/arah yang bebeda) dan currere (lari).

Dalam perkembangannya, kata discourse lebih banyak digunakan oleh para ahli bahasa dalam kajian linguistik sedangkan istilah discursus beserta bentuk adjetifnya diskursif lebih banyak digunakan oleh para ilmuwan sosial (Mulyana \& Yahya, 2005). Laclau dan Mouffe dalam (W. Jorgensen dan Philips, 2007) mengemukakan bahwa praktik apapun yang berusaha menetapkan hubungan di antara unsur-unsur sehingga identitasnya berubah sebagai akibat 
praktik artikulatoris kami sebut dengan artikulasi. Totalitas terstruktur yang berasal dari praktik artikulatoris kami sebut sebagai wacana.

Analisis wacana kritis (critical discourse analysis) adalah analisis bahasa dalam penggunaannya dengan menggunakan paradigma bahasa kritis. Analisis wacana kritis, yang lebih sering disebut AWK dilihat sebagai oposisi analisis wacana deskriptif yang melihat wacana sebagai teks bahasa semata. AWK terdiri atas teori dan metode yang sekiranya dapat digunakan untuk melakukan kajian empiris tentang keterkaitan antara wacana dan perkembangan sosial serta budaya dalam pengaruh sosial yang berbeda (Darma, 2014).

Analisis wacana kritis memiliki lima karakteristik. Pertama, yaitu tindakan, wacana dipahami sebagai sebuah tindakan (action) dengan kata lain adanya bentuk interaksi. Kedua, yaitu konteks, artinya wacana dikaitkan dengan latar, situasi, peristiwa, dan kondisi. Ketiga, yaitu histori yang berrati wacana dikaitkan dengan sejarah atau keadaan yang ada sebelumnya. Keempat, yaitu kekuasaa artinya terjadi hubungan antara kelas atas dan kelas bawah dala masyarakat. Karakteristik wacana kritis yang terakhir adalah ideologi. (Eriyanto, 2001).

Analisis wacana kritis melihat bahasa sebagai faktor penting, yakni betapa bahasa digunakan untuk melihat ketimpangan kekuasaan dalam masyarakat (Fairclough, 2001). Menurut M.Wetherell dalam (Haryatmoko, 2016) analisis wacana kritis merupakan penerapan analisis kritis terhadap bahaya yang terinspirasi oleh Marxisme ketika menyoroti aspek-aspek budaya dalam kehidupan sosial, yaitu ketika dominasi dan eksploitasi dipertahankan melalui budaya dan ideologi.

Berdasarkan uraian dan pendapat para ahli, maka analisis wacana kritis tidak hanya dianggap sebagai kajian bahasa, meskipun bahasa dalam teks yang menjadi objek analisisnya, tetapi hasil dari analisis tersebut tidak hanya bertujuan untuk memperoleh gambaran dari aspek kebahasaan, akan tetapi juga berkaitan dengan konteks, tindakan, historis, kekuasaan, dan ideologi. Dalam melakukan kajian empiris tentang hubungan antara wacana dan perkembangan kultural dalam domaindomain yang berbeda, terdapat beberapa model analisis wacana kritis yang dapat digunakan sebagai pisau bedah dalam kajian tersebut.

\section{B. Slogan}

Menurut Widyatama dalam (Samosir dkk., 2016) menyatakan bahwa slogan merupakan susunan kata, frasa, maupun klausa yang bersifat menarik, serta mudah diingat untuk mewakili tujuan suatu perusahaan Slogan merupakan penggambaran arah sebuah perusahaan serta menentukan posisi produk di tengah masyarakat. Slogan menjadi salah satu hal penting untuk memperkenalkan produk kepada masyarakat sebab dapat menjadi ciri khas. Pemilihan bahasa dalam slogan dapat dikatakan sebagai wujud branding dari calon kandidat pilkada Sulawesi Selatan untuk memperkenalkan dirinya. Menurut (Husna, 2017) branding adalah sebuah strategi yang dilakukan oleh aktor politik dalam melakukan komodifikasi atas identitas dirinya secara berbeda dari para competitor agar terlihat lebih berharga, stand out dan menarik di mata konstituen dengan menggunakan media sebagai pintu masuknya. Wacana slogan caleg memiliki penyampaian kepada masyarakat umum yang cukup beragam. Pada dasarnya, skema slogan caleg terdiri atas struktur yang umum, di antaranya butir utama (headline, badan (body), dan penutup (close). 
Akhmad, dkk (2019) menyatakan bahwa slogan dapat menjadi identitas suatu produk, sehingga masyarakat mudah mengingat produk dari sebuah perusahaan. Slogan tersebut dapat meningkatkan pengetahuan masyarakat terhadap produk. Sesuai dengan yang dikemukakan oleh Akhmad (2019), Sukma (2018) menyatakan bahwa slogan bertujuan untuk menarik perhatian dan simpati para calon pemilihnya.

Berdasarkan uraian-uraian tersebut maka disimpulkan bahwa slogan politik adalah kata, frase, klausa atau kalimat pendek yang mencolok, menarik, dan mudah diingat yang digunakan oleh calon kepala daerah pada saat kampanye. Slogan politik bertujuan untuk mengajak, mempengaruhi, memotivasi, dan memberikan informasi kepada masyarakat agar memilih calon kepala daerah tersebut.

\section{Bahasa Politik dalam Pertarungan Simbolik}

Bahasa politik adalah bahasa yang digunakan dalam berpolitik, misalnya bahasa slogan atau propaganda, bahasa para pemegang kekuasaan dalam berpidato atau bahasa pidato pimpinan partai, dan tulisan yang berbau politik yang tentu saja semua bahasa yang digunakan itu mengandung maksud untuk mencapai tujuan tertentu. Satu hal yang paling harus kita perhatikan dalam penggunaan bahasa ini adalah ditetapkannya ideologi. Jadi, bahasa itu harus bisa diterima akal sehat atau menjadi pengetahuan umum (commonsense) bagi si pendengar atau pembaca. Jika ideologi tertentu diungkapkan menggunakan bahasa politik maka tujuan politis dari politisi tersebut telah tercapai.

Selain bahasa Indonesia, bahasa daerah juga kerap digunakan dalam slogan plkada. Penggunaan bahasa daerah bertujuan meimbulkan penghargaan atau rasa hormat, keakraban, terhadap lawan bicara. Hal inilah yang menjadi dasar kandidat yang mengikuti pemilihan kepala daerah menggunakan bahasa daerah dalam slogan kampanyenya. Dengan menggunakan bahasa daerah, mereka akan menunjukkan kesetaraan dan rasa kebersamaan kepada masyarakat.

Berdasarkan uraian tersebut maka dapat disimpulkan bahwa bahasa politik dalam pertarungan simbolik adalah satu kesatuan yang tidak dapat dipisahkan. Bahasa politik adalah bahasa yang digunakan dalam dunia politik. Seseorang yang terjun ke dunia politik harus mampu menguasai bahasa politik agar mampu mencapai tujuannya termasuk memahami bahasa daerah.

\section{Teori Pemikiran Pierre Bourdie 1. Pierre Bourdie}

Pierre Bourdieu merupakan salah seorang tokoh sosiologi kultural. Lahir di Denguin Pyrenia Atlantik (Perancis) sekitar 91 tahun yang lalu. Pegawai kantor pos merupakan profesi ayah dari Pierre Bourdieu Karirnya di jenjan pendidikan dimulai dari lycee di Pau, selanjutnya mengenyam pendidikan di sekolah menengah atas (lycee), Louisle-Grand (Paris), beliau mengambil Fakultas sastra di Paris. Pada tahun 1951, Bourdieu melanjutkan pendidikan ke Ecole Normale Superieure, yang merupakan salah satu institusi pendidikan elit di Paris. Bourdieu mengajar di Lycee Moulins sebelum pada akhirnya pada tahun 1951 mendapat wajib militer bersama tentara Prancis ke Aljazair.

Sekitar tahun 1958-1960 ia mengabdikan diri mengajar di fakultas sastra di Alger sekaligus melakukan penelitian empiris mengenai masyarakat Aljazair. Bourdieu pernah mengajar dibeberapa tempat di antaranya Sarbonne selama dua tahun (1961-1962), ia 
mengajar di Universitas Lille (19611964). Kemudian ia diangkat menjadi direktur di Pusat Kajian Sosiologi Eropa (Centre de Sociologie Europeenne), Fauzil (2014:48).

\section{Habitus, Modal, Ranah}

Menurut Lubis dkk dalam (Siregar, 2016), konsep habitus merupa-kan kunci sintesis teoretis Bourdieu. Sejalan dengan itu, Bourdieu mengemukakan bahwa habitus merupakan kombinasi dari sebuah sistem yang terstruktur yang terjadi secara objektif dan melibatkan sejarah personal, pendapat yang berlangsung lama dan berubah-ubah menjadi basis generatife bagi praktik-praktik yang terstruktur dan terpadu secara objektif. Habitus menjadi sebuah bentuk pembatinan nilai sosial budaya yang beraneka ragam dan rasa permainan (feel for the game) yang melahirkan bermacam gerakan yang sejalan dengan proses yang berlangsung. Habitus adalah bentuk penghayatan tatanan dunia sosial, atau tatanan sosial yang dilakukan, Fashri dalam (Siregar, 2016).

(Fatmawati, 2010) mengemukakan bahwa gagasan utama Boudieu dalam memahami masyarakat adalah terletak pada konsep habitus dan arena, juga strategi untuk mencapai dan mempertahankan kekuasaan. Penjabaran habitus secara menyeluruh mengandaikan suatu bentuk epistemologi sejarah dalam arti mengungkap relevansi praktis suatu wacana. Habitus dalam bahasa latin memiliki arti segala sesuatu yang berkaitan dengan kebiasaan, pencerminan diri, atau pembawaan diri yang terkait dengan kondisi tipe tubuh. Pierre Bourdieu mengemukakan habitus sebagai penyesuaian yang berkaitan dengan syarat adanya suatu kelas. Menurutnya sistem perbedaan yang diwariskan, tatanan yang membentuk suatu kebiasaan merupakan hasil dari suatu habitus. Sejalan dengan itu dapat disimpulkan bahwa habitus adalah hasil keterampilan yang merupakan tindakan praktis (tidak selalu disadari) yang selanjutnya dijabarkan melalui kemampuan yang terlihat alamaiah dan mengalami perkembangan dalam lingkungan sosial tertentu (Fatmawati, 2010)

Rusdiarti (dalam Syaf, 2017) mengemukakan bahwa habitus bahasa diperoleh dengan menginternalisasi struktur dunia sosial objektif tempat ia hidup, dan karenanya bervariasi bergantung pada kondisi pembetukannya. Misalnya, seorang yang tumbuh akrab dengan buku, majalah, dan bahan bacaan yang dianggap "bermutu" akan memiliki kosakata yang banyak, cara berfikir teratur, wawasan yang luas, dan pengetahuan yang dibutuhkannya. Sebuah praktik berbahasa atau diskursus dihasilkan oleh habitus, yang disebut habitus bahasa. Habitus bahasa adalah disposisi-disposisi untuk mengha-silkan, memahami, menilai dan menggunakan bahasa secara tepat dalam berbagai kondisi. Habitus bahasa secara mendalam meliputi kemampuan untuk menghasilkan sekaligus menilai bahasa, dialek, gaya bahasa, diksi, gaya pengucapan, intonasi, logat, aksen, mimik tertentu dan lain-lain (Syaf, 2017).

Habitus berkaitan dengan modal. Modal dalam pengertian Bourdieu mencakup beberapa aspek diantaranya aspek ekonomi, aspek budaya, dan aspek simbolik yang yang secara umum didayahgunakan untuk mendapatkan dan mempertahankan perbedaan dan dominasi. Modal harus selalu disejajarkan dengan ranah, agar ranah menjadi bermakna. Penerimaan aktor dalam suatu tindakan sosial sangat dipengaruhi oleh modal yang dimiliki. Modal ini bersifat elastis artinya dapat terjadi pertukaran modal yang satu dengan modal yang lain. Akomodasi modal merupakan hal yang sangat penting di dalam ranah (Harker, dkk dalam (Siregar, 2016). 
Konsep ranah, arena atau medan (field) merupakan ruang atau semesta sosial tertentu sebagai tempat para agen/aktor saling bersaing. Ranah/arena menjadi tempat para aktor bertarung untuk mendapatkan kekuatan simbolis. Pertarungan ini bertujuan mendapatkan sumber yang lebih banyak sehingga terjadi perbedaan antara pesaing yang satu dengan yang lain. Artinya, semakin banyak sumber yang dimiliki maka hal itu berbanding lurus dengan struktur yang dimiliki. Perbedaan inilah yang memberi struktur hierarki sosial dan mendapat legitimasi seakan-akan menjadi suatu proses yang alamiah, Lubis dkk dalam (Siregar, 2016).

Berdasarkan uraian tersebut, dapat diketahui perbedaan habitus, modal, dan arena. Habitus sebagai pengkondisian yang dikaitkan dengan syarat-syarat keberadaan suatu kelas. Modal adalah kemampuan yang dimiliki oleh individu maupun kelompok dalam memperjuangkan ideologinya baik berupa modal ekonomi, budaya, maupun modal simbolik sedangkan arena atau ranah adalah ruang atau semesta sosial tertentu sebagai tempat para agen/aktor saling bersaing.

\section{E. Bahasa, Ideologi, dan Kuasa dalam Pertarungan Wacana}

Rusdianti dalam (Jufri, 2014), mengemukakan bahasa sebagai praktik sosial, bahasa merupakan hasil interaksi antara struktur sosial dengan habitus linguistik. Jagat sosial menurut Bourdieu merupakan arena pertarungan atau ranah saling menunjukkan dominan. Sebagai ranh persaingan, pihak yang mendominasi akan ditentukan oleh kepemilikan terhadap modal kapital. Aktor yang mendominasi terhadap kepemilikan modal kapital akan menjadi pemenang dalam pertarungan. Modal kapital dapat berupa ekonomi, budaya, sosial, dan simbolik.
Modal inilah yang menjadi pendorong individu atau kelompok tertentu dalam memperebutkan kekuasaan. Kekuasaan merupakan kemampuan untuk bertindak atau memerintah sehingga dapat menyebabkan orang lain bertindak sesuai dengan apa yang diperintahkan, maksudnya adalah orang yang memerintah harus mampu mempengaruhi orang lain dan mengatasi pelaksanaan keputusan itu, French dan Revan dalam (Nasruddin, 2013). Sesuai dengan pendapat tersebut (Jufri, 2014) mengemukakan bahwa kekuasaan merupakan bentuk pengontrolan yang dilakukan individu dan kelompok terhadap individu atau kelompok lainnya. Kekuasaan tersebut dapat dimaknai sebagai bentuk kontrol /pembatasan institusi atau orang lain. Jadi, kekuasaan mengisyaratkan adanya pihak yang dikontrol dan pihak yang mengontrol.

(Jufri, 2014) mengemukakan bahwa pertarungan simbolik yang terjadi di jagat sosial merupakan upaya untuk mencapai kekuasaan simbolik. Pertarungan simbolik adalah sebuah persaingan untuk kekuasaan atau pelaku sosial yang lain untuk menunjukkan eksistensi dan penguasaan atas pandangan dan persepsi. Tujuan akhir dalam pertarungan ini adalah mendapatkan kekuasaan untuk memproduksi dan menunjukkan kepada dunia sebagai pihak yang paling diakui, paling benar, dan paling memiliki legitimasi. Pertarungan simbolik tersebut melibatkan wacana dominan dan wacana yang mencoba merebut dominasi.

Individu atau kelompok yang telah berkuasa secara langsung akan mempengaruhi objek kekuasaan melalui ideologinya. (Subhkan, 2018) menyatakan bahwa Ideologi, politik dan kekuasaan adalah hal yang tidak terpisahkan. Ideologi mengacu pada apa yang orang pikir dan percaya menegnai masyarakat, kekuasaan, hak, tujuan kelompok, yang semuanya mejadi penentu tindakan 
mereka. Penentu dalam hal ini adalah batasan terhadap tindakan atau perbuatan yang akan dilakukan dalam kehidupan sehari-hari. Selanjutnya, Eriyanto dalam (Suharyo dkk., 2015) mengemu-kakan bahwa ideologi adalah dialektika kekuasaan yang tidak seimbang (dominasi marginal).

Bourdieu (Karnanta, 2013), menyatakan bahwa kekuasaan simbolik merupakan bentuk kekuasaan yang digunakan untuk mengubah dan mewujudkan kenyataan, yaitu mengubah dan menciptakannya sebagai sesuatu yang diakui, dikenali dan juga sah. Kuasa simbolik bertujuan membuat orang memandang dan meyakini cara pandang yang diinginkan oleh aktor yang mendominasi. Analisis pertarungan simbolik yang terjadi dalam sebuah wacana dilakukan dengan mengkaji dua aspek wacana, yakni eufemisme dan sensorisasi. Aspek eufimisme adalah bentuk pertarungan simbolik yang memiliki mekanisme tidak tampak, bekerja secara halus, tidak dikenali dan berlangsung di bawah alam bawah sadar. Sementara itu, aspek sensorisasi dilakukan melalui mekanisme perentangan moral kehormatan dan moral rendah. Bentukbentuk eufimisasi dapat berupa kepercayaan, kewajiban, kesetiaan, sopan santun, pemberian, pahal, belas kasihan, Rusdianti dalam (Jufri, 2014).

Berdasarkan uraian tersebut, maka hubungan antara bahasa, ideologi dan kekuasaan dalam pertarungan simbolik merupakan satu kesatuan untuk melanggengkan kekuasaan dan ideologi suatu individu maupun kelompok melalui mekanisme eufemisasi dan sensorisasi yang terdapat dalam slogan pilkada Sulawesi selatan tahun 2020 .

\section{METODE}

Jenis penelitian yang digunakan adalah penelitian deksriptif yang bertujuan untuk menyajikan gambaran lengkap suatu permasalahan secara objektif guna menemukan suatu informasi dan fakta yang sebenarnya. Jenis penelitian deskriptif yang digunakan dalam penelitian ini mengacu pada pendekatan kualitatif. Adapun tjuan penelitian ini yaitu merepresentasikan kata, frase, klausa, atau kalimat yang menunjukkan bentuk-bentuk pertarungan simbolik dalam slogan pilkada Sulawesi Selatan tahun 2020. Fokus penelitian ini berfokus pada dua rumusan masalah yaitu bentuk pertarungan simbolik aspek eufemisasi dan aspek sensorisasi dalam slogan pilkada Sulawesi Selatan tahun 2020 menurut teori Pierre Bourdieu. Desain penelitian yang digunakan adalah deskriptif kualitatif dengan pendekatan teori AWK Pierre Boudieu dalam slogan kampanye pilkada Sulawesi Selatan tahun 2020.

Data dalam penelitian ini adalah kata, frase, klausa, dan kalimat yang yang berisi slogan pilkada Sulawesi Selatan tahun 2020. Sumber data dalam penelitian ini adalah media cetak berupa spanduk, banner, baliho dan stiker kampanye kandidat pilkada Sulawesi Selatan tahun 2020. Selanjutnya, data dikumpulkan melalui tiga teknik yaitu teknik dokumentasi, teknik baca, dan teknik catat.

Terakhir yaitu teknik analisis data. Analisis data dalam penelitian ini menggunakan teori AWK Pierre Bourdieu yang terdiri dari mekanisme kekerasan simbolik berupa bentuk eufemisasi dan sensorisasi yang melalui empat tahap yaitu, tahap identifikasi data, reduksi data, penyajian data, dan kesimpulan.

\section{HASIL DAN PEMBAHASAN}

Penyajian hasil analisis data didasarkan atas pemahaman peneliti dengan teori analisis wacana kritis Bourdie. Berikut beberapa contoh analisi data bentuk pertarungan aspek eufemisasi. 


\section{a. Bentuk eufemisasi) \\ Perubahan}

Bentuk perubahan adalah kondisi yang menunjukkan keadaan berbeda dengan keadaan sebelumnya. Perubahan memiliki makna peralihan dari satu keadaan ke keadaan lain yang menunjukkan terwujudnya kondisi lebih baik atau justru sebaliknya. Data bahasa sebagai praktik sosial ditemukan dalam penelitian ini disajikan sebagai berikut.

data 01 (SLY)

data 02

"Untuk perubahan coblos No.1!"

\section{data 03 \\ data 04

$$
\text { “Terus bergerak!” (BLK) }
$$

"Insyaallah Bulukumba lebih baik” (BLK)

"Dua kali tambah lebih baik" (MKS)

\section{data 05}

\section{"Luwu Timur lebih baik” (LT)}

Berdasarkan data tersebut, bentuk perubahan dikonstruksi oleh calon kepala daerah untuk mendapatkan simpati dari masyarakat. Data (01) termasuk kalimat perintah yang dipersepsikan kepada publik sebagai tujuan. Namun demikian, istilah perubahan masih sebagai wacana. Perubahan yang dimaksudkan tidak didefenisikan secara spesifik hanya dipersepsikan sebagai suatu keadaan yang berubah. Melalui eufemisasi jenis ini, ideologi calon kepala daerah diupayakan dengan cara yang halus. Pemilihan kata "perubahan" sebelum frasa "coblos No.1!" menunjukkan kata perintah yang dikontruksi secara halus. Jadi, calon kepala daerah menjanjikan perubahan terlebih dahulu sebelum megajak masyarakat untuk memilihnya.

Berdasarkan data (03), calon kepala daerah menggunakan frasa kata kerja "terus bergerak" dalam upaya mendapatkan simpati dan dukungan dari masyarakat. Bergerak ialah melakukan suatu usaha, berpindah dari tempat yang satu ke tempat yang lain (tidak diam), berusaha giat, dan mengadakan aksi yang bertujuan menciptakan perubahan. Upaya tersebut dilakukan dengan menjanjikan suatu usaha yang akan dilakukan secara giat. Usaha pergerakan itu dapat diwujudkan melalui kegiatan dalam bidang pembangunan, perekonomian, pendidikan, kesehatan, dan kegiatan sosial lainnya untuk mensejahterahkan masyarakat. Salah satu sektor yang menjadi sumber utama pendapatan daerah di Kabupaten Bulukumba adalah sektor wisata. Melalui sektor ini, calon kepala daerah mampu menggerakkan wilayah tersebut menjadi semakin baik.

$$
\text { Data (02), (04), dan }
$$
menggunakan bentuk perubahan melalui kosakata komparatif. Kosakata komparatif adalah kosakata yang bermakna perbandingan, jadi calon kepala daerah membandingkan perubahan yang akan dilakukan dengan calon kepala daerah yang lain. Ciri utama kosakata komparatif adalah penggunaan kata lebih. Kosakata komparatif yang ditemukan dalam slogan pilkada Sulawesi Selatan tahun 2020 yaitu "lebih baik".

Penggunaan kosakata komparatif pada data (02), (04) dan (05) merupakan bentuk strategi calon kepala daerah menawarkan perubahan kepada masyarakat. Jika pada data (01), perubahan yang ditawarkan tidak spesifik, maka pada data (02), (04) dan (05) sudah lebih spesifik karena perubahan yang dimaksud adalah perubahan yang lebih baik.

\section{b. Bentuk sindiran (aspek sensorisasi)}

Sindiran adalah perkataan yang bermaksud menyindir orang; celaan (ejekan dan sebagainya) yang dilakukan secara tidak langsung. Bentuk sensorisasi ini dapat dilihat pada data berikut ini. data 30

\section{data 31}




\section{"1 bukti lebih baik dari 1000 janji” (MKS)}

Berdasarkan data (30) dan (31), aktor politik menggunakan bahasa dalam slogan tersebut dengan cara menyindir lawan politiknya untuk memengaruhi masyarakat. Calon kepala daerah pada data (30) memosisikan dirinya sebagai kandidat yang nantinya akan bersungguhsungguh bekerja tanpa bercerita banyak atau dengan kata lain tidak banyak berjanji. Realitas yang banyak terjadi di kalangan penguasa adalah memberikan banyak janji dan perencanaan pada masa kampanye, namun setelah terpilih mereka seolah lupa dengan janji yang pernah diucapkan. Melalui sensorisasi bentuk sindiran ini, aktor politik menyindir lawan politiknya sekaligus memengaruhi masyarakat bahwa mereka akan langsung memberikan bukti berupa kerja nyata.

Data (31), "1 bukti lebih baik dari 1000 janji” merupakan slogan yang diusung oleh kandidat petahana calon walikota Makassar dengan menggunakan kosakata komparatif. Masyarakat diajak untuk berpikir bahwa sebagai kandidat petahana, kandidat tersebut telah memberikan bukti nyata sementara lawan politiknya masih sekadar janji. Mengetahui rekan jejak calon kepala daerah merupakan salah satu cara menentukan pilihan, namun bagi masyarakat kalangan menengah ke bawah biasanya akan lebih mudah terpengaruh dengan banyaknya janji-janji politik yang ditawarkan. Janji kesejahteraan melalui pembukaan lapangan kerja, pendidikan gratis, kesehatan gratis, dan sebagainya telah menjadi program andalan bagi calon kepala daerah untuk mendapapatkan simpati masyarakat.

Berdasarkan hasil penelitian yang berjudul Pertarungan Simbolik dalam Slogan Pilkada Sulawesi Selatan Tahun 2020 ditemukan dua hal yang menjadi jawaban dari rumusan masalah yang telah dipaparkan pada bagian awal atau pendahuluan dari tesis ini. Kedua hal tersebut yaitu bentuk pertarungan simbolik aspek eufemisasi dan bentuk pertarungan simbolik aspek sensorisasi.

Menurut Pierre Bourdieu, terdapat dua aspek mekanisme kekerasan simbolik yang digunakan dalam pertarungan simbolik. Rusdiarti dalam (Jufri, 2014), mengemukakan bahwa aspek eufemisasi adalah elemen kekerasan simbolik yang tidak tampak, bekerja secara halus, tidak dapat dikenali, dan berlangsung di alam bawah sadar. Eufemisasi tidak hanya melihat pada persoalan penghalusan bahasa, tetapi juga menyangkut penyamaran maksud, atau makna di balik sebuah tuturan lisan maupun tulisan, sehingga sulit untuk dikenali dan bahkan dirasakan sebagai sesuatu yang wajar. Aspek yang kedua yaitu sesnsorisasi. Aspek ini diartikan sebagai sebuah proses yang menjadikan kekerasan simbolik tampak sebagai bentuk dari pelestarian semua bentuk nilai yang dianggap moral kehormatan yang dipertentangkan dengan moral rendah.

Berdasarkan aspek eufemisasi, bentuk pertarungan simbolik yang ditemukan terdiri atas bentuk perubahan, bentuk kebangkitan, bentuk keren, bentuk harapan, bentuk kesediaan, bentuk pengulangan/lanjutkan, bentuk kebersamaan, bentuk persatuan, bentuk kesejahteraan, bentuk kebaruan, bentuk identitas sosial, dan bentuk merakyat. Selanjutnya, aspek sensorisasi terdiri atas bentuk sindiran, kejujuran, dan kesantunan.

Penggunaan bentuk eufemisasi dilakukan dengan cara tersembunyi, halus, masif dan terjadi di alam bawah sadar. Penggunaan kata yang memiliki makna lebih halus bertujuan mendatangkan nilai positif dengan harapan masyarakat tertarik memilih kandidat tersebut. Sekaitan dengan hal itu, Fairchlogh (2003), mengemukakan bahwa eufemisasi digunakan untuk menggantikan kata lain 
dengan tujuan untuk menjadikannya lebih konvensional dan lebih dikenal sebagai upaya untuk menghindari nilai-nilai negatif.

Bentuk eufemisasi yang pada umumnya ditemukan yaitu mengarah pada bentuk "perubahan". Namun secara spesifik bentuk ini digunakan oleh beberapa kandidat calon kepala daerah. Penggunaan bentuk "perubahan" oleh calon kepala daerah bertujuan untuk menunjukkan keadaan berbeda dengan keadaan sebelumnya. Perubahan memiliki makna peralihan dari satu keadaan ke keadaan lain. Analisis data penggunaan bentuk perubahan ditemukan menggunakan penekanan yang ditandai dengan pemilihan kosakata komparatif. Kosakata komparatif adalah kosakata yang bermakna perbandingan, jadi calon kepala daerah membandingkan perubahan yang akan dilakukan dengan calon kepala daerah yang lain. Ciri utama kosakata komparatif adalah penggunaan kata "lebih". Kosakata komparatif yang ditemukan dalam slogan pilkada Sulawesi Selatan tahun 2020 yaitu "lebih baik". Adapun calon kepala daerah yang menggunakan kosakata komparatif dalam slogan kampanyenya terdiri dari pasangan calon 01 Kabupaten Bulukumba, paslon 01 Kota Makassar, dan paslon 02 Kabupaten Luwu Timur.

Selain sebagai strategi politik untuk mendapatkan dukungan masyarakat, penggunaan "bentuk perubahan" melalui kosakata komparatif, juga dipilih calon kepala daerah untuk menunjukkan kemampuannya dalam melakukan perubahan lebih unggul dari calon kepala daerah yang lain. Lebih lanjut, penggunaan kosakata komparatif juga pernah ditemukan oleh Jufri dan Tolla (2014) melalui judul penelitian Representasi Pertarungan Simbolik dalam Wacana Iklan Komersil. Dalam penelitian tersebut, kosakata komparatif yang ditemukan terdiri atas lebih irit, lebih ringan, lebih gesit, dan lebih efektif. Menurut Jufri dan Tolla (2014), penggunaan kosakata komparatif dalam wacana iklan merupakan bentuk strategi produsen untuk mencitrakan diri sebagai produk yang lebih baik dibanding produk lainnya.

Pemilihan bentuk eufemisasi ini juga sangat berkaitan dengan posisi kandidat calon kepala daerah baik yang berstatus kandidat petahana maupun nonpetahana. Bentuk "lanjutkan", bentuk dan bentuk "merakyat", merupakan bentuk simbolik yang digunakan oleh kandidat petahana. Sementara bentuk "kebersamaan", bentuk "kebaruan", bentuk "usia muda", bentuk "persatuan", dan bentuk "perubahan" dipilih oleh kandidat nonpetahana. Namun, pada intinya pemilihan bentuk-bentuk kekerasan simbolik tersebut memiliki satu tujuan yaitu menanamkan ideologi kepada masyarakat untuk kepentingan kekuasaan.

Temuan bentuk-bentuk aspek eufemisasi ini memiliki beberapa kesamaan dengan hasil penelitian yang dilakukan oleh peneliti sebelumnya. Penelitian yang dilakukan oleh Jufri (2014) dengan judul penelitian Pertarungan Simbolik dalam Wacana Calon Legislatife menemukan bentuk aspek eufemisasi yang terdiri atas bentuk aspirasi, bentuk kebaikan, bentuk kebersamaan, bentuk keharusan, bentuk anjuran, bentuk berani, bentuk demi rakyat, bentuk cara berpolitik, bentuk informasi, bentuk janji, bentuk keadilan, bentuk keagungan, bentuk kelebihan, bentuk kemajuan, bentuk kemakmuran, bentuk kemudaan, bentuk kepedulian, bentuk kepercayaan, bentuk kesejahteraan, bentuk kesetaraan, bentuk ketegasan, bentuk komitmen, bentuk konsisten, bentuk kualitas, bentuk maaf, bentuk martabat, bentuk mengarahkan, bentuk pembuktian, bentuk pembangunan, bentuk pemikiran, bentuk pengalaman, bentuk pengandaian, bentuk pengorbanan, 
bentuk penyelamatan, bentuk perbuatan, bentuk semangat, bentuk totalitas, dan bentuk puisi. Selanjutnya, bentuk sensorisasi yang dtemukan terdiri atas bentuk bersih, bentuk kedermawanan, bentuk keikhlasan, bentuk keluhuran, dan bentuk moral.

Selanjutnya, kesamaan hasil penelitian yang dilakukan oleh Syaf (2017) dengan judul penelitian Pertarungan Simbol Identitas Etnis Sebagai Komunikasi Politik dalam Pilkada Kota Makassar yaitu terletak pada penggunaan bahasa daerah. Pada penelitian terdahulu penggunaan tagline “Ana' Lorongna Makassar", digunakan oleh Ramdhan Pomantho untuk membangun konektifitas antar modal kultural masyarakat Kota Makassar. Sekaitan dengan hal tersebut, dalam penelitian ini terdapat salah satu kandidat Walikota Makassar yakni pasangan nomor urut 03, menggunakan konektifitas kultural dan emosional pemilih melalui slogan "Sombere'na Makassar". Penggunaan bahasa daerah bertujuan menunjukkan kesetaraan dan rasa kebersamaan antara dirinya dengan masyarakat.

Secara umum, melalui penelitian yang telah dilakukan pada slogan pilkada Sulawesi Selatan Tahun 2020, peneliti menemukan sebanyak delapan belas bentuk efemisasi dan tiga bentuk sensorisasi seperti yang telah dikemukakan sebelumnya. Berdasarkan hasil tersebut dapat dinyatakan bahwa terdapat beberapa bentuk pertarungan simbolik pada aspek eufemisasi yang tidak disebutkan oleh Pierre Bourdieu dalam teorinya. Penemuan bentuk-bentuk eufemisasi selain yang disebutkan oleh Pierre Bourdieu juga ditemukan pada hasil penelitian terdahulu misalnya yang ditemukan oleh Jufri dalam dua judul penelitiannya.

Pada aspek sensorisasi, hasil penelitian ini menunjukkan tiga bentuk sensorisasi yaitu sindiran, kejujuran, dan kesantunan. Dari ketiga bentuk sensorisasi tesebut, bentuk sindiran dan kejujuran tidak terdapat dalam Teori Bourdieu. Akan tetapi, perlu dipahami bahwa Pierre Bourdieu tidak membatasi bentuk-bentuk eufemisasi maupun sensorisasi yang dapat muncul dalam sebuah penelitian. Penyebab perbedaan bentuk eufemisasi dan bentuk sensorisasi yang ditemukan dalam sebuah penelitian salah satunya dipengaruhi oleh objek kajian.

\section{KESIMPULAN}

Hasil dalam penelitian ini ditemukan bentuk pertarungan simbolik dalam slogan pilkada Sulawesi-Selatan Tahun 2020. Bentuk pertarungan simbolik aspek eufemisasi dalam slogan pilkada Sulawesi Selatan tahun 2020 terdiri atas bentuk perubahan, kebangkitan, keren, harapan, kesediaan, lanjutkan, kebersamaan, persatuan, kesejahteraan, kebaruan, identitas sosial, dan merakyat. Bentuk pertarungan simbolik aspek sensorisasi dalam slogan pilkada Sulawesi Selatan tahun 2020 terdiri atas bentuk sindiran, kesantunan, dan kejujuran.

\section{DAFTAR PUSTAKA}

Akhmad Ramli, dkk (2019). Slogan Politik Lokal Pada Media Baliho: Suatu Kajian Semantik. Jurna Pendidikan Bahasa No. 2, Volume 8, Agustus 2019.

Darma, Y. A. (2014). Analisis Wacana Kritis Dalam Multiperspektif. PT. Refika Aditama.

Departemen Pendidikan Nasional. (2008). Kamus Besar Bahasa Indonesia Pusat Bahasa (IV). PT. Gramedia Pustaka Utama.

Eriyanto. (2001). Analisis wacana: Pengantar analisis teks media (Cet. 1). LKiS Yogyakarta.

Fairclough, N. (2001). Language and power (2nd ed). Longman. 
Fashri, F. (2016). Pierre Bourdieu:
$\begin{gathered}\text { Menyingkap Kuasa Simbol. } \\ \text { Jalasutra. }\end{gathered}$

Fatmawati, N. ika. (2010). Pierre Bourdieu dan Konsep Dasar Kekerasan Simbolik. Jurnal Politik dan Sosial Kemasyarakatan, Jurnal Politik dan Sosial Kemasyarakatan Vol. 12 No. 1.

Hanafi, R. I. (2014). Pemilihan Langsung Kepala Daerah Di Indonesia: Beberapa Catatan Kritis Untuk Partai Politik. Jurnal Penelitian Politik, Volume 11, 16.

Haryatmoko. (2016). Critical Discourse Analysis (Analisis Wacana Kritis). PT. Raja Grafindo Persada.

Jufri. (2014). Pertarungan Simbolik dalam Wacana Calon Legislatif: Kajian Kritis. Badan Penerbit UNM.

Jufri, \& Tolla, A. (2014). Representasi Linguistik dalam Pertarungan Simbolik Wacana Iklan Komersil. Jurnal Penelitian Pendidikan Insani, Jurnal Penelitian Pendidikan Insani Volume 16, No. 1, Hal. 72-76.

Jørgensen, M., \& Phillips, L. (2007). Analisis wacana: Teori \& metode. Pustaka Pelajar.

Karnanta, K. Y. (2013). Padigma Teori Arena Produksi Kultural Sastra: Kajian Terhadap Pemikiran Pierre Bourdieu. Jurnal Poetika, Jurnal Poetika. Vol.1 No. 1.

Samosir, D. K., Nurhayati, I. K., \& Maulana, S. (t.t.). Hegemoni Penggunaan Bahasa Iinggris dalam Slogan Perguruan Tinggi
(Analisis Wacana Kritis Nourman Fairchlough Pada Slogan Dua Universitas Swasta di Kota Bandung). 12.

Siregar, M. (2016). Teori "Gado-gado" Pierre Bourdieu. Vol. I No 2:7982.

Subhkan, E. (2018). Ideologi, Kekuasaan, dan Pengaruhnya Pada Arah Sistem Pendidikan Nasional Indonesia (1950-1965). Journal Of Indonesian History, Volume 7 No. 1 .

Suharyo, Surono, \& Amin, M. (2015). Representasi Ideologi dan Kekuasaan dalam Bahasa Kajian Teks Media. Jurnal Humanika, Volume 22 No.2.

Sukma, B.P. (2018). Sistem Appraisal Pada Slogan Dalam Kain Rentang Kampanye Politik Bakal Calon Kepala Daerah Kabupaten Dan Kota Bogor. Ranah: Jurnal Kajian Bahasa. Volume 7, No. 2, Hal.

Syaf, E. J. (2017). Pertarungan Simbol Identitas Etnis Sebagai Komunikasi Politik dalam Pilkada Kota Makassar. Komunikasi Kareba, Komunikasi Kareba Vol. 6 No. 2.

Zurmailis, \& Faruk. (2017). Doksa, Kekerasan Simbolik dan Habitus Yang Ditumpangi dalam Kontruksi Kebudayaan di Dewan Kesenian Jakarta. Jurnal Bahasa dan Sastra, Jurnal Bahasa dan Sastra Vol. I No. 1. 